\title{
Penanggulangan Kecanduan Game Online Melalui Pendidikan Karakter Regilius Pada Anak
}

\author{
Moch. Tohet \\ Universitas Nurul Jadid Paiton Probolinggo \\ elheds78@gmail.com \\ Sofiya Mauliza \\ Universitas Nurul Jadid Paiton Probolinggo \\ maulizasofiya@gmail.com
}

\begin{abstract}
The purpose of this study was to instill religious characters in children who are addicted to online games in Langkap village, Bringin hamlet, Besuki, Situbondo through 1) Megrib reciting movement 2) Reading shalawat nariya 3) Routine memorization 4) and showing Islamic films. The method used is a qualitative descriptive approach. This research was conducted in Langkap Village, Bringin Hamlet, Besuki, Situbondo. The subjects in the study, namely parents, village officials, and children who are addicted to online games. This research was conducted so that children who are addicted to online games can be overcome and their dependence on online games can be minimized and as a form of gratitude and love for Allah SW'T and the Prophet SAW. The implication in overcoming addiction to online games through religious character education is one of the positive impacts for children, namely that children are not constantly fixated on online games, and make children tend to do things that are more useful and have a better personality than before.
\end{abstract}

Keywords: Online Game; Copping Religious Character

Abstrak: Tujuan dari penelitian ini adalah untuk menanamkan karakter religius pada anak yang kecanduan game online di desa Langkap, dusun Bringin, Besuki, Situbondo melalui 1) Gerakan megrib mengaji 2) Pembacaan shalawat nariya 3) Hafalan rutinan 4) dan Tayangan film Islami. Metode yang digunakan adalah pendekatan Deskriptif Kualitatif. Penelitian ini dilaksanakan di Desa Langkap, dusun Bringin, Besuki, Situbondo. Subjek dalam penelitian, yaitu orang tua, kepala desa, dan anak yang kecanduan game online. Penelitian ini dilakukan agar anak-anak yang kecanduan game online dapat ditanggulangi dan diminimalisir ketergantungannya terhadap game online dan sebagai wujud syukur dan cinta kepada Allah SWT dan Nabi SAW. Implikasi dalam penanggulangan kecanduan game online melalui pendidikan karakter regilius menjadikan salah satu dampak positif bagi anak yaitu anak tidak terus-menerus terpaku pada permainan game online, dan menjadikan anak cenderung melakukan hal-hal yang lebih bermanfaat dan memiliki kepribadian yang lebih baik dari sebelumnya.

Kata Kunci: Game Online; Kecanduan; Karakter Religius. 


\section{PENDAHULUAN}

Kemajuan teknologi saat ini sangat pesat dan semakin canggih. ${ }^{1}$ Banyak teknologi yang telah diciptakan membawa perubahan besar dalam kehidupan sehari-hari. Sampai saat ini perkembangan dan pengetahuan telah mengantar masyarakat menuju babak baru yaitu memanfaatkan peralatan-peralatan yang merupakan hasil dari teknologi sebagai sarana penyediaan informasi dan komunikasi. Dari teknologi itu pula, orang dapat memanfaatkannya sebagai perangkat untuk penggunaan internet. ${ }^{2}$ Melalui internet, orang dapat mencari dan berkomunikasi dengan berbagai informasi.

Perkembangan teknologi yang semakin pesat, menjadi tantangan baru bagi generasi muda. Salah satu teknologi yang banyak digunakan oleh kalangan masyarakat yaitu gadget. Dengan berkembangnya teknologi dari tahun ke tahun maka berpengaruh juga terhadap perkembangan gadget yang dimiliki. Seperti penambahan beberapa fitur yang telah dikenal dan cukup trending dalam kalangan masyarakat. Salah satu fitur yang tidak sedikit penggunanya terutama di kalangan muda yaitu game online.

Game online merupakan suatu fitur yang diciptakan sebagai permainan yang bisa dimainkan di dunia maya. Berbagai jenis game online yang dipublikasikan dalam gadget memengaruhi minat seorang anak untuk menggunakannya. Hal itu dapat menyebabkan daya tarik yang tinggi bagi seorang anak. ${ }^{4}$ Namun, tidak banyak dari mereka yang mampu menyaring serta memilih permainan yang baik untuk digunakan yang sesuai dengan usia mereka, sehingga menjadikan tertanamnya sikap negatif serta perilaku yang tidak baik yang disebabkan oleh game online itu sendiri. ${ }^{5}$

Salah satu dampak negatif yang muncul dari penggunaan internet yakni adanya berbagai permainan online yang disediakan. Penggunaan game online telah mendapat banyak perhatian dari masyarakat luas. Game online dapat dimainkan oleh siapa saja pada waktu bersamaan melalui jaringan internet. Sejak

${ }^{1}$ Chusna, Asmaul, and Puji, "Pengaruh Media Gadget Pada Perkembangan Karakter Anak,” Dinamika Penelitian: Media Komunikasi Sosial Keagamaan 17, no. 2 (2017): 315-30.

${ }^{2}$ Suharyanto and Cosmas Eko, "Peran Teknologi Informasi Dan Komunikasi (Tik) Sebagai Enabler Knowledge Management Dalam Membawa Inovasi Pada Industri Kreatif Di Batam," no. 1322202122 (2019), https://doi.org/10.31227/osf.io/ag2nk.

${ }^{3}$ Yuli Salis Hijriyani and Ria Astuti, "Penggunaan Gadget Pada Anak Usia Dini Dalam Menghadapi Era Revolusi Industri 4.0," ThufuLA: Jurnal Inovasi Pendidikan Guru Raudhatul Athfal 8, no. 1 (2020): 015, https://doi.org/10.21043/thufula.v8i1.6636.

${ }^{4}$ Zubir, Zahriyanti, and Yuhafliza, "Pengaruh Media Sosial Terhadap Anak Dan Remaja," Pendidikan Almuslim VII, no. 1 (2019): 10-15.

${ }^{5}$ Putri Hana Pebriana, "Analisis Penggunaan Gadget Terhadap Kemampuan Interaksi Sosial Pada Anak Usia Dini," Jurnal Obsesi : Jurnal Pendidikan Anak Usia Dini 1, no. 1 (2017): 1, https://doi.org/10.31004/obsesi.v1i1.26. 
kemunculannya game online menjadi sangat populer dan mudah untuk diakses oleh seseorang, sehingga menjadikan mereka lengah dan menyepelekan kegiatan positif lainnya. Sebenarnya game online jika dimainkan hanya untuk hiburan dan tidak dimainkan dalam waktu lama tidak akan berdampak negatif. Namun jika pengguna atau pemain menjadi kecanduan maka akan berdampak negatif. ${ }^{6}$

Dalam permainan online, pemain dapat menggunakan kekerasan untuk menghadapi musuh mereka, dan melakukan segala cara untuk memenangkan pertempuran. Dengan ini anak-anak akan menjadi terbiasa melakukan aktivitas yang ada di game online tersebut. Namun, selain menggunakan kekerasan anak juga sering mengeluarkan kata-kata kasar saat bermain game online. ${ }^{7}$ Beberapa permainan game online yang mengandung kekerasan seperti Power Blank (PB) dan Player Unknown Battleground (PUBG) dan konten seluler legend penuh dengan perilaku yang bertentangan dengan pendidikan karakter anak. ${ }^{8}$ Ketika perilaku ini berlanjut di dunia nyata, muncul kekhawatiran, di mana anak-anak tumbuh dengan karakter yang tidak islami sama sekali, yaitu: saat anak tumbuh dewasa, mereka hanya akan peduli pada diri mereka sendiri, ingin memenangkan diri sendiri, dan menghalalkan segala cara demi mendapatkan apa yang mereka inginkan, dan anak akan tumbuh pada tingkat emosional yang tinggi. Selain itu, anak yang kecanduan bermain game online seringkali terbiasa membuang-buang waktu. Melihat realita ini, tentu saja kita menjadi paham bahwa bermain game online secara berlebihan akan berdampak negatif pada kepribadian anak yang sangat kontras dengan pendidikan karakter yang senantiasa mengajarkan kesantunan, kelembutan, kedamaian, dan cinta sayang yang bertujuan menjadikan pribadi yang lebih baik, bertakwa kepada Tuhan Yang Maha Esa, dan memelihara hubungan baik dengan manusia dan lingkungannya.

Permasalahan yang terjadi di dusun Bringin, desa Langkap, Besuki, Situbondo adalah banyaknya anak yang kecanduan game online. Banyak anak di desa tersebut yang menghabiskan waktunya untuk bermain game online lebih dari dua jam/hari, atau lebih dari 14 jam/minggu sehingga mengakibatkan anak kecanduan pada permainan tersebut. Dari fenomena yang sering terjadi khususnya pada anak usia sekolah dasar, merupakan suatu hal yang perlu diperhatikan dan memerlukan pendekatan khusus. Fenomena yang terjadi

${ }^{6}($ Kurniawan 2017

${ }^{7}$ (Amran et al. 2020

${ }^{8}$ Nurbaiti, "Kecanduan Bermain Game Online Dan Hubungannya Dengan Pendidikan Karakter Islami Siswa (Studi Di SD Azhari Cilandak Jakarta)," Jurnal Kajian Ilmu Dan Budaya Islam 3, no. 1 (2020): 55-67.

"Saihu Saihu, "Pendidikan Karakter Berbasis Kearifan Lokal (Studi Di Jembrana Bali)," Edukasi Islami: Jurnal Pendidikan Islam 8, no. 01 (2019): 69, https://doi.org/10.30868/ei.v8i01.364. 
biasanya disebabkan kurangnya perhatian dari orang tua dan upaya yang dilakukan secara intensif dalam menangani anak yang bermain game online secara berlebihan yang sebetulnya bisa dilakukan oleh lingkungan di mana anak itu tinggal. Oleh karena itu, upaya penanganan dapat dilakukan dengan menggunakan strategi yang tidak jauh berbeda dari kesenangan mereka bermain game online.

Guna meminimalisir dampak negatif yang disebabkan oleh game online, pendidikan karakter menjadi salah satu solusi yang paling efektif. Pendidikan karakter yaitu pendidikan utama yang harus diajarkan kepada anak-anak, terutama ketika mereka masih berada di bangku sekolah dasar. Pendidikan karakter merupakan dasar utama keberhasilan seseorang dalam kehidupannya. ${ }^{10}$ Pendidikan karakter memiliki makna pendidikan mempelajari kepribadian, yang berarti menghubungkan dengan berbagai aspek, di antaranya aspek pengetahuan (cognitive), perasaan (feeling), dan tindakan (action). ${ }^{11}$ Mengenai penerapan pendidikan karakter tersebut bisa melalui media apa saja yang terdapat di sekitar anak. Media tersebut seperti, keluarga, lembaga pendidikan, lingkungan masyarakat, sistem pemerintahan, kawasan usaha, serta media masa. ${ }^{12}$ Sementara itu, penerapan pendidikan karakter di dunia pendidikan berfungsi sebagai berikut: (1) menciptakan kehidupan nasional dalam budaya yang berbeda-beda (multikultural), (2) mewujudkan budaya cerdas dan berakhlak mulia, dan (3) mewujudkan sikap dan tindakan masyarakat yang kreatif, mandiri, cinta damai dan hidup berdampingan dengan bangsa dan masyarakat yaitu, keharmonisan berbangsa dan bernegara. ${ }^{13}$

Pendidikan karakter secara umum bertujuan untuk mengembangkan kemampuan individu agar bisa menentukan keputusan yang baik dan buruk, menjaga hal-hal yang baik, serta mewujudkan hal baik tersebut dalam kehidupan sehari-hari ${ }^{14}$. Selain itu, pendidikan karakter dibutuhkan untuk menanggulangi

\footnotetext{
${ }^{10}$ Hendro Widodo, "Penguatan Pendidikan Karakter Di SD Muhammadiyah Macanan Sleman Yogyakarta," Jurnal Lentera Pendidikan 22, no. 1 (2019): 40-51.

11 Setyaningrum et al., "Optimalisasi Penerapan Pendidikan Karakter Di Sekolah Menengah Berbasis Keterampilan Proses: Sebuah Perspektif Guru IPA-Biologi," Jurnal Penelitian Dan Pemikiran Pendidikan 1, no. 1 (2020): 69-81.

12Purandina et al., "Pendidikan Karakter Di Lingkungan Keluarga Selama Pembelajaran Jarak Jauh Pada Masa Pandemi COVID-19," Cetta: Jurnal Ilmu Pendidikan 3, no. 2 (2020): 270-90, https://doi.org/10.37329/cetta.v3i2.454.

${ }^{13}$ Kadek Arta Jaya, "Membangun Mutu Pendidikan Karakter Siswa Melalui Implementasi Ajaran Tri Hita Karana," Jurnal Penjaminan Mutu 5, no. 1 (2019): 57, https://doi.org/10.25078/ipm.v5i1.759.

14 Munif et al., "STRATEGI GURU DALAM MEMBENTUK KARAKTER SISWA MELALUI NILAI-NILAI KEJUJURAN," Fondatia: Jurnal Pendidikan Dasar 5, no. 2 (2021): $163-79$.
} 
permasalahan moral dan akhlak yang tidak baik di masa modern, terutama dalam mengatasi dampak negatif yang ditimbulkan oleh game online ${ }^{15}$. Sebab, apabila dampak negatif tersebut dibiarkan, maka karakter generasi penerus bangsa akan hancur.

Selaras dengan konsep pendidikan karakter tersebut, dusun Bringin mengadakan beberapa kegiatan rutin seperti gerakan Magrib mengaji, pembacaan shalawat nariyah, hafalan surat pendek, serta menonton film Islami sebagai bentuk internalisasi pendidikan karakter religius. Kegiatan rutin tersebut dilakukan pada malam hari di mana anak banyak menghabiskan waktunya untuk bermain game. Kemendikbud telah menyatakan bahwa pendidikan karakter religius meliputi 3 dimensi yaitu, hubungan individu dengan Tuhan, hubungan individu dengan individu, serta hubungan individu dengan lingkungan, Pendidikan karakter religius diperlukan untuk membangun pondasi dasar dalam membentuk karakter yang berdasarkan pada nilai-nilai keagamaan ${ }^{16}$. Dalam hal ini, kegiatan rutin yang dilaksanakan di dusun Bringin juga berupaya untuk disesuaikan dengan 3 dimensi sebagaimana tersebut di atas.

Pendidikan karakter religius penting untuk ditanamkan sebab dapat mengkonstruksi perkataan, pikiran, serta tindakan anak agar selalu berdasarkan nilai dan norma ketuhanan ${ }^{17}$. Hal tersebut dapat menjadi solusi efektif dalam mengatasi dampak negatif yang ditimbulkan oleh kecanduan game online. Lebih lanjut lagi, pelaksanaan kegiatan rutin di dusun Bringin sebagai internalisasi pendidikan karakter religius akan menjadi wadah untuk menanamkan kepribadian yang positif guna mewujudkan hikmah dari apa yang dipelajari ${ }^{18}$. Dalam hal ini, dusun Bringin merupakan lingkungan sosial sebagai faktor eksogen yang dapat mempengaruhi terbentuknya karakter religius ${ }^{19}$.

\footnotetext{
${ }^{15}$ Fathor Rozi and Innani Kholidatul Jannah, "Revitalisasi Pemberdayaan Budaya Karakter Nuansa Religiustik Dalam Membentuk Perilaku Pekerti Santri," Murobbi: Jurnal Ilmu Pendidikan 5, no. 1 (2021): 17-34.

${ }^{16}$ Lisa Retnasari, Suyitno Suyitno, and Yayuk Hidayah, "Penguatan Peran Taman Pendidikan AlQuran (TPQ) Sebagai Pendidikan Karakter Religius," Jurnal SOLMA 8, no. 1 (2019): 32, https://doi.org/10.29405/solma.v8i1.2968.

${ }^{17}$ Lyna Dwi Muya Syaroh and Zeni Murtafiati Mizani, "Membentuk Karakter Religius Dengan Pembiasaan Perilaku Religi Di Sekolah: Studi Di SMA Negeri 3 Ponorogo," Indonesian Journal of Islamic Education Studies (IJIES) 3, no. 1 (2020): 63-82, https://doi.org/10.33367/ijies.v3i1.1224.

${ }^{18}$ Siswanto Siswanto, Ifnaldi Nurmal, and Syihab Budin, "Penanaman Karakter Religius Melalui Metode Pembiasaan," AR-RLAYAH: Jurnal Pendidikan Dasar 5, no. 1 (2021): 1, https://doi.org/10.29240/jpd.v5i1.2627.

${ }^{19}$ Rina Rahmi, Aswatun Hasanah, and Septika Laily Anti, "Konsep Pendidikan Karakter Pada Sekolah Inklusi Tingkat Usia Dasar," AR-RIAY AH : Jurnal Pendidikan Dasar 4, no. 2 (2020): 155, https://doi.org/10.29240/jpd.v4i2.1648.
} 
Sebagai perbandingan agar mendapat pembahasan yang mendalam, peneliti mengkaji penelitian terdahulu yang memiliki relevansi dengan topik penelitian ini. Seperti penelitian yang dilakukan oleh Ismi memberikan kesimpulan bahwa dampak bermain game online terhadap perilaku anak akan berdampak baik, yaitu banyak memiliki teman sedangkan dampak buruknya yaitu minat anak dalam belajar akan semakin menurun. Sehingga upaya yang dapat dilakukan yaitu kerja sama antar orang tua dan guru melalui bimbingan dengan memberikan nasihat kepada anak, melakukan razia gadget dan memeriksa sosial media yang diikutinya. ${ }^{20}$ Sedangkan Novrialdy berpendapat bahwa bermain secara berlebihan akan membuat terganggunya kegiatan seharihari, anak akan mengubah prioritasnya dan memiliki minat sangat rendah terhadap hal-hal yang tidak berhubungan dengan game online. ${ }^{21}$

Penelitian ini lebih difokuskan kepada penerapan pendidikan karakter religius pada anak agar tidak kecanduan game online, dalam hal ini terdapat perbedaan yang sangat signifikan dalam hasil yang akan dicapai antara peneliti sebelumnya dengan penelitian ini. Selain itu, penelitian ini memiliki keunikan dan pembaharuan. Keunikan yang terdapat dalam penelitian ini salah satunya adalah sifat antusias anak dalam melakukan suatu kegiatan untuk menanamkan karakter pada dirinya. Sedangkan pembaharuan yang terdapat dalam penelitian ini terletak pada penerapan yang dilakukan pada anak melalui pendidikan karakter dengan menerapkan karakter regilius. Tentu tujuan ini akan sulit tercapai apabila yang menjadi hambatan tidak dicegah atau diminimalisir. Berdasarkan hal tersebut, penelitian ini penting untuk dilakukan pada anak di dusun Bringin, desa Langkap, kecamatan Besuki, kabupaten Situbondo khususnya anak yang ada sedang menempuh pendidikan dasar yang sangat gemar bermain game online, dimana pada masa-masa tersebut anak banyak yang mengalami pertumbuhan yang pesat pada aspek jasmani dan ruhaninya.

Penelitian ini menggunakan pendekatan Deskriptif Kualitatif. jenis penelitian field research (penelitian lapangan) yang mana pengumpulan data berdasarkan hasil wawancara dan observasi yang mengacu kepada realitas/fenomena yang terjadi secara alamiah pada objek atau subjek penelitian secara mendalam untuk mendapatkan fenomena yang menarik perhatian yang ada dilingkungan desa tersebut yang diperoleh dari informasi yang diteliti.

\footnotetext{
${ }^{20}$ Nurul Ismi and Akmal Akmal, "Dampak Game Online Terhadap Perilaku Siswa Di Lingkungan SMA Negeri 1 Bayang," Journal of Civic Education 3, no. 1 (2020): 1-10, https://doi.org/10.24036/jce.v3i1.304.

${ }^{21}$ Novrialdy and Eryzal, "Kecanduan Game Online Pada Remaja: Dampak Dan Pencegahannya Online Game Addiction in Adolescents : Impacts and Its Preventions" 27, no. 2 (2019): 148-58, https://doi.org/10.22146/buletinpsikologi.47402.
} 
Subjek dalam penelitian ini adalah orang tua, aparat desa, dan anak yang kecanduan game online. Adanya penelitian ini peneliti fokus kepada bagaimana desa tersebut menaggulangi anak yang kecanduan game online dengan menggunakan pendidikan karakter religius. Analisis yang diambil di lakukan secara sistematis yang mana semua itu dimulai dari penyajian data reduksi data yang dilakukan dengan memilih dan menyeleksi setiap data yang masuk dari hasil observasi dan wawancara, diolah, dan berakhir dengan penarikan kesimpulan.

\section{PEMBAHASAN}

Penelitian ini memfokuskan pada penanggulangan kecanduan game online melalui pendidikan karakter religius. Pendidikan karakter religius adalah upaya aktif untuk membentuk suatu sikap dan perilaku yang patuh pada ajaran agama yang dianutnya, menumbuhkan sikap saling menghormati dan menghargai antar individu ataupun pada pemeluk agama lainnya. ${ }^{22}$ Pendidikan karakter merupakan salah satu pembentukan kepribadian seseorang yang mana hasilnya dapat dilihat di kehidupan nyata. ${ }^{23}$ Dalam kamus Besar Bahasa Indonesia didefinisikan bahwa kepribadian sama halnya dengan suatu sifat yang menyatu dengan kejiwaan, perilaku, atau kepribadian seseorang hingga ia dapat membedakan dua aspek yang berbeda-beda dari seseorang. Pendidikan karakter juga dapat diartikan sebagai suatu sistem penanaman nilai-nilai perilaku atau karakter pada anak, yang melingkupi kesadaran, pengertian, kepedulian, dan komitmen, termasuk nilai-nilai baik untuk Tuhan, individu, masyarakat, lingkungan, dan lainnya. ${ }^{24}$

Menurut Oktari, Pendidikan karakter adalah sebuah proses transformasi nilai-nilai kehidupan untuk ditumbuhkembangkan dalam kepribadian seseorang, dan menjadikan perilaku yang baik dalam kehidupan anak. ${ }^{25}$ Oleh sebab itu pendidikan karakter merupakan proses menanamkan suatu nilai positif pada anak agar memiliki kepribadian yang baik yang setara dengan nilai yang diajarkan baik dari agama, budaya, ataupun bangsa.

${ }^{22}$ Chandra et al., "Pendidikan Karakter Religius Dan Toleransi Pada Santri Pondok Pesantren Al Hasanah Bengkulu," Al-Tadækiyyah: Jurnal Pendidikan Islam 11, no. 02 (2020): 11132.

23(Arkani and Hari 2017;

${ }^{24}$ Munif et al., "STRATEGI GURU DALAM MEMBENTUK KARAKTER SISWA MELALUI NILAI-NILAI KEJUJURAN.”

${ }^{25}$ Dian Popi Oktari and Aceng Kosasih, "Pendidikan Karakter Religius Dan Mandiri Di Pesantren," Jurnal Pendidikan Ilmu Sosial 28, no. 1 (2019): 42, https://doi.org/10.17509/jpis.v28i1.14985. 
Membentuk karakter laksana mengukir gambar di atas batu permata atau permukaan besi yang keras. Pendidikan karakter juga dapat dikatakan sebagai suatu sistem penanaman nilai perilaku atau karakter pada anak, yang mencangkup kesadaran, pengertian, kepedulian, dan komitmen, terutama pada nilai baik untuk Tuhan, individu, masyarakat, lingkungan, dan lainnya, agar bangsa menjadi universal, seseorang secara alami dapat menjadi pribadi yang sempurna. ${ }^{26}$

Pembentukan karakter wajib dilakukan secara sistematis dan berkesinambungan yang melibatkan aspek "knowledge, feeling, loving dan acting". Pada dasarnya, anak yang kualitas karakternya rendah merupakan anak yang tingkat perkembangan emosi-sosialnya rendah, sehingga berakibat besar anak mengalami kesulitan dalam melakukan segala hal misalnya, dalam belajar, berinteraksi sosial, dan ketidakmampuan untuk mengontrol diri. ${ }^{27}$

Dari hasil observasi dan wawancara yang peneliti lakukan, didapatkan hasil dari para orang tua atau warga sekitar, ditemukan banyak terjadi kasus kecanduan game online pada anak. Mirisnya, banyak anak yang masih duduk di bangku sekolah dasar yang cenderung selalu bermain game online. Mereka biasanya akan bermain game online bersama dengan teman-teman sebayanya di luar rumah, tepatnya di warung-warung kecil dan di sebuah gandrung yang terdapat di desa tersebut. Anak desa Langkap bisa menghabiskan waktu bermain game lebih dari $2 \mathrm{jam} / \mathrm{hari}$ atau bahkan mampu lebih dari $14 \mathrm{jam} /$ minggu. Tidak hanya itu, menurut hasil wawancara dan observasi, banyak anak di desa tersebut yang mengabaikan kewajiban utamanya untuk beribadah akibat terlalu asyik bermain game online. Gejala ini disikapi oleh kepala desa yang merasa ikut bertanggung jawab untuk mengatasi permasalahan tersebut, dengan bekerja sama dengan orang tua dan masyarakat sekitar untuk menanggulangi anak yang sering bermain game online dengan menanamkan nilai karakter religius anak.

Penanggulangan merupakan upaya yang dilakukan untuk mencegah, menyambangi, atau melampaui suatu keadaan yang mencakup sebuah aktivitas. ${ }^{28}$ sekaligus berupaya untuk memperbaiki perilaku seseorang. Kata lain dari penanggulangan dapat dilakukan secara preventif yaitu upaya pencegahan agar

${ }^{26}$ Moch Tohet and Ida Rositha, "Penguatan Kurikulum 2013 Dalam Menumbuhkan Karakter Peserta Didik Di Sekolah,” Jurnal At-Tarbiyat 1, no. 2 (2019), https://doi.org/10.30649/fisheries.v1i2.23.

${ }^{27}$ Zainun Wafiqatun Niam, "Membina Karakter Anak Melalui Program Full Day School Berbasis Nilai-Nilai Kepesantrenan (Studi Kasus Di Madrasah Ibtidaiyah Nurul Ummah Kotagede Yogyakarta)," BELAJEA: Jurnal Pendidikan Islam 4, no. 1 (2019): 19, https://doi.org/10.29240/belajea.v4i1.696.

${ }^{28}$ Tomohon and D I Kota, "Peran Dinas Sosial Dalam Penanggulangan Kenakalan Anak Remaja Di Kota Tomohon," Jurnal Politico 10, no. 4 (2021). 
tidak terjadi penyimpangan, dan represif yaitu upaya pencegahan bila telah terjadi penyimpangan. ${ }^{29}$

Maka dari hasil penelitian ini beberapa bentuk penanggulangan anak kecanduan game melalui pendidikan karakter religius yang dilakukan oleh kepala desa yang bekerja sama dengan orang tua anak di Desa Langkap, dusun Bringin Besuki Situbondo yaitu :

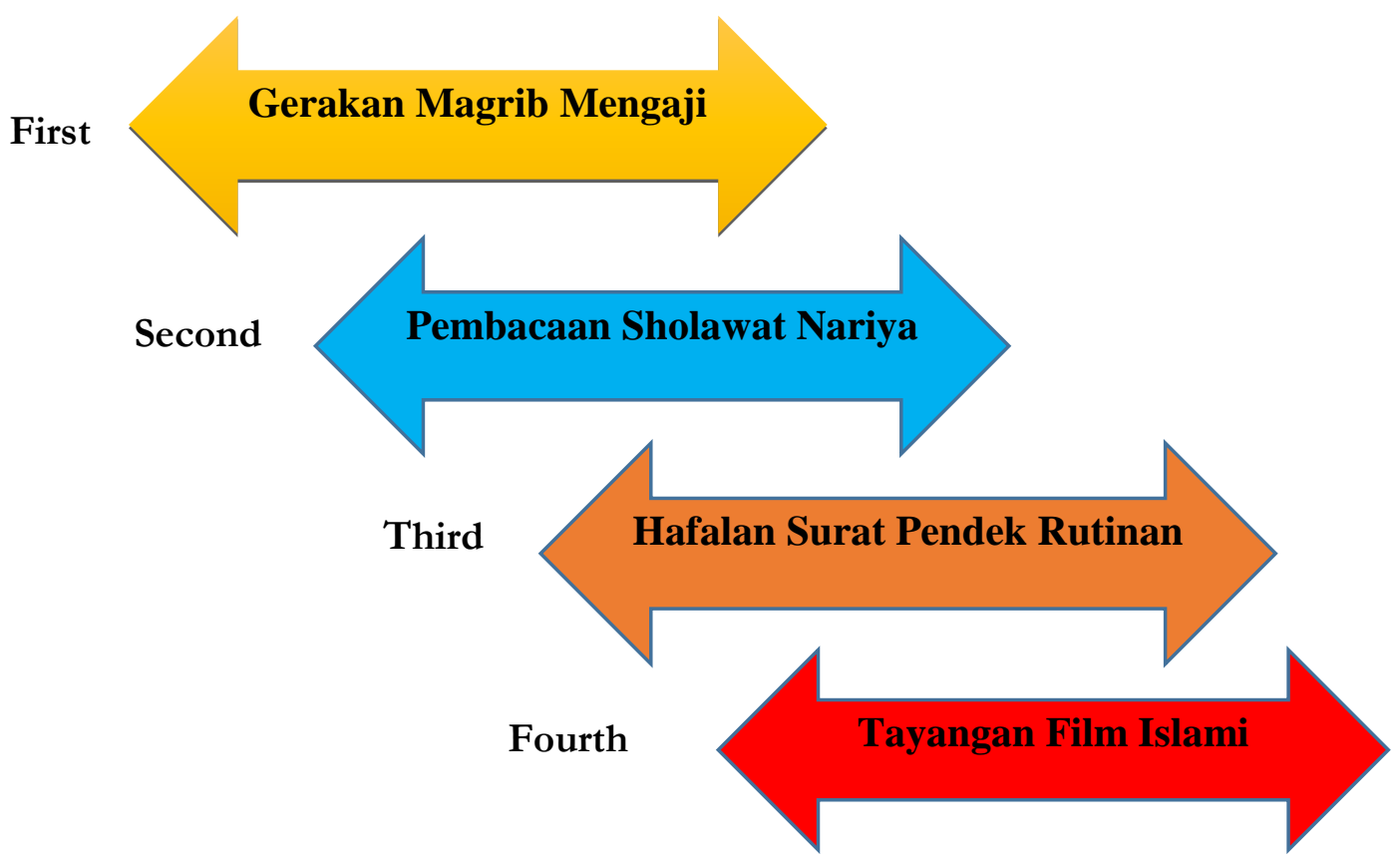

\section{Gerakan Magrib Mengaji}

Kepala desa menghidupkan kembali tradisi membaca al-Quran setiap selesai salat Magrib di musala-musala yang ada di desa tersebut, dengan harapan anak yang kecanduan game online bisa memanfaatkan waktunya antara Magrib dan Isya dengan efektif untuk beribadah kepada Allah, memperdalam wawasan keagamaan dan tidak menghabiskan waktunya untuk hal yang kurang bermanfaaat. Tetapi, dengan adanya globalisasi dan modernisasi saat ini

\footnotetext{
${ }^{29}$ Setyowati and Dewi Liesnoor, "Pendidikan Kebencanaan," Urgensi Pendidikan Mitigasi Bencana, 2019, 1-14.
} 
menjadikan ruang, tempat, dan waktu di dunia tidak ada batasnya juga pesatnya kemajuan dan inovasi teknologi tiap waktunya yang menjadikan berbagai aktivitas dan mobilisasi mudah dilakukan, sehingga menimbulkan efek kepuasan sesaat dan kurangnya perencanaan terhadap beberapa hal yang tadinya merupakan prioritas, tetapi mulai dianggap sebagai aktivitas luang, salah satunya aktivitas mengaji al-Qur'an setelah salat Magrib.

Menurut Saputra mengaji merupakan sebuah kegiatan ibadah seorang muslim sebagai bentuk keimanan bagi pemeluk-Nya kepada tuhan Yang Maha Esa dan diharapkan mewujudkan keakraban dan kecintaan terhadap AlQuran. ${ }^{30}$ Berdasarkan definisi tersebut, maka dapat dipahami bahwa mengaji merupakan suatu rangkaian dari kegiatan ibadah untuk mewujudkan dan sebagai bentuk kecintaan terhadap Yang Maha Kuasa. Jadi, esensi dari mengaji tentu merupakan sumber pahala dan syukur dari umat muslim itu sendiri. Sehingga, seluruh umat muslim diharapkan dapat menjalankan ibadah tersebut dimanapun dan kapanpun. Maka dari itu, upaya yang dilakukan oleh kepala desa untuk menghidupkan kembali tradisi membaca Al-Quran setiap selesai salat Magrib adalah salah satu cara yang tepat.

Mengaji adalah ibadah utama sejak awal perkembangan Islam Nusantara. Namun perkembangannya saat ini mengalami perubahan pada perilaku manusia sehingga mengaji semakin ditinggalkan oleh ummat muslim. ${ }^{31}$ Sehingga, hal tersebut menjadi fokus utama untuk membenahi munculnya pergeseran karakter yang mana sudah bertentangan dengan norma/kebiasaan umat Islam, yang seharusnya menjadi perhatian khusus, karena pembentukan karakter anak akan memengaruhi pola perilakunya dimasa mendatang.

Gerakan mengaji sendiri yaitu suatu gerakan untuk membudayakan kegiatan membaca al-Quran setelah salat Magrib di kalangan masyarakat baik perkotaan maupun pedesaan yang bertujuan untuk menghidupkan kembali budaya mengaji saat Magrib yang sebenarnya sudah mengakar jauh di Indonesia. ${ }^{32}$ Maka dari itu, pelaksanaan program ini diharapkan mampu mengatasi dan meminimalisir hal-hal yang tidak diinginkan sebagai bentuk dampak dari adanya kepesatan teknologi dan maraknya game online. Hal tersebut dilakukan, agar anak-anak tetap menjalankan dan tak lupa dengan kewajibannya terhadap mengaji yang akan menuntun di akhirat kelak.

${ }^{30}$ Ganda Ade Saputra, "Masyarakat Magrib Mengaji” 15, no. 2 (2019): 164-70.

${ }^{31}$ Kartika et al., "Pelaksanaan Gerakan Masyarakat Magrib Mengaji Di Nagari Lubuk Basung Kabupaten Agam," Journal of Civic Education 1, no. 2 (2018): 141-48, https://doi.org/10.24036/jce.v1i2.185.

${ }^{32}$ Jumanah et al., "Revolusi Mental Melalui Penerapan Kebijakan Gerakan Magrib Mengaji Di Kabupaten Lebak," Transparansi : Jurnal Ilmiah Ilmu Administrasi 3, no. 2 (2020): 160_ 66, https://doi.org/10.31334/transparansi.v3i2.1098. 


\section{Pembacaan Shalawat Nariyah}

Pembacaan shalawat bersama yang dilakukan setiap Selasa malam yang dilaksanakan di masjid yang ada di dusun-dusun tersebut, di mana pembacaan shalawat Nariyah ini menjadi salah satu upaya menanggulangi anak yang kecanduan game online. Pembacaan shalawat dilakukan agar anak-anak mampu bertafakur diri dan menjadi bentuk kecintaan pada Nabi dan Rasul-Nya.

Kegiatan ini setidaknya mengurangi waktu bermain game online bagi anak-anak. Pembacaan shalawat ini dipimpin oleh para takmir masjid dan dilakukan setelah salat Magrib. Kegiatan ini dilaksanakan sebagai bentuk ikhtiar salah satu cara mencintai nabi Muhammad SAW, sebagai pembawa risalah bagi umat Islam, menekuni perilaku-perilakunya, dan menunjukkan identitas bahwa Situbondo adalah kota bumi Shalawat Nariyah.

Agar tidak menimbulkan kebosanan, maka pada kegiatan rutin pembacaan shalawat ini juga diberikan mauizah hasanah/wejangan yang diberikan secara bergilir, baik oleh tokoh agama maupun tokoh masyarakat. Tujuan pembacaan sholawat tidak hanya lantunan pujian yang ditunjukkan kepada Nabi SAW, namun pembacaan shalawat juga bisa untuk mendekatkan anak pada nilai-nilai Islami sekaligus melestarikan sabda Nabi dalam tradisi yang nyata. ${ }^{33}$ Maka dari itu, pembacaan shalawat yang dilakukan oleh anak-anak selain sebagai upaya menanggulangi perilaku kecanduan game juga sebagai upaya untuk meningkatkan ketaqwaan kepada Allah SW'T dan kecintaan kepada Nabi Muhammad SAW.

Shalawat merupakan suatu kajian yang sangat esensial (penting) dan bermanfaat untuk dikaji oleh kita. Pada zaman modern ini, shalawat merupakan salah satu hal yang harus diprioritaskan. Sebab, pada kenyataanya banyak masyarakat yang masih belum tahu tentang arti sesungguhnya dari shalawat. ${ }^{34}$ Maka sebagai umat muslim kita wajib membaca dan melestarikan dan mengamalkan shalawat. Dengan membaca shalawat hati kita akan lebih tenang dan dapat menanamkan nilai karakter religius pada anak.

\section{Hafalan Surat Pendek Rutinan}

Untuk memberikan pemahaman keagamaan kepada anak-anak, juga dilakukan kegiatan hafalan surat-surat pendek al-Qur'an dan dilaksanakan

${ }^{33}$ Mufidah et al., "Tradisi Sholawat Mansub Habib Sholeh Bin Muhsin Al-Hamid Di

Tempeh Tengah, Lumajang," Jurnal Living Hadis 5, no. 1 (2020): 59, https://doi.org/10.14421/livinghadis.2020.2205.

${ }^{34}$ Fahruroji \& Yunus Chairul Azhar, "Perspektif Shalawat Di Dalam Al-Qur'an Dan AlHadits Serta Implikasinya Di Dalam Penafsiran Dan Penetapan Hukum," Jurnal Pendidikan BASIS Babasa Arab Dan Studi Islam 1, no. 1 (2017): 31-40. 
dengan model pembiasaaan dengan dijadwal secara bergilir. Anak-anak yang mampu menghafal surat-surat pendek al-Quran secara baik dan benar diberi reward, sementara anak-anak yang memiliki keterlambatan dalam menghafal diberik motivasi. Tujuan dari hafalan rutinan ini selain daya ingat anak lebih meningkat, agar anak juga lebih mengenal ayat-ayat al-Quran yang menjadi sumber hukum pertama dan utama dalam Islam.

Muhammad Zakaria berpendapat, bahwa hafalan akan tetap diingat setelah melakukan tiga proses yaitu: pertama encode, yakni memasukan ke dalam sistem memori melalui indra. Kedua storage, yaitu penyimpanan informasi yang telah diberi kode ke dalam otak. Dan yang ketiga recall (retrieval), yakni mengingat kembali informasi setelah disimpan dengan baik di dalam otak kita dan di tuangkan dalam bentuk ucapan, tulisan, isyarat, atau sekedar banyangan di dalam otak. ${ }^{35}$ Tahapan dalam menghafal sesungguhnya sangat bervariatif, dan tidak bisa disamaratakan pada setiap individu. Tetapi, apabila ditinjau dari paparan yang dikemukakan tersebut maka dapat dipahami bahwa terdapat beberapa proses penting untuk menghafal yang membantu mempermudah hafalan tersebut. Sehingga anak-anak dapat dengan santai menikmati prosesnya tanpa merasa terbebani. Hafalan yang dilakukan tersebut juga sebagai upaya agar anak-anak terbiasa dengan hal-hal bermanfaat dan berfungsi untuk menstimulus otak.

Napiah juga berpendapat bahwa hafalan bukan serta merta menghafalkan saja, tetapi merupakan usaha dengan sadar dan bersungguhsungguh yang dilakukan untuk mengingat dan meresapkan bacaan-bacaan ke dalam fikiran. ${ }^{36}$ Selain itu, manfaat dari menghafal bukan semata-mata untuk diri pribadi tetapi juga untuk orang-orang sekitar, karena limpahan pahala juga syafaat yang didapat sebagai penolong di hari akhir dan di akhirat kelak.

Menghafal merupakan sesuatu yang susah, tetapi ada sebagian yang mengatakan menghafal itu sesuatu yang mudah apalagi bagi yang sudah terbiasa, dia akan merasakan betapa besar manfaat menghafal, belum lagi kalau dia penghafal al-Qur'an yang tentunya sudah dijelaskan keutamaannya. ${ }^{37}$ Meskipun

${ }^{35}$ Din Muhammad Zakariya, "METODE MUDAH MENGHAFAL AL-QUR'AN MENURUT DR. AHMAD SALIM," Jurnal Pendidikan Islam 9, no. 2 (2019): 33-47.

${ }^{36}$ Napiah et al., "Meningkatkan Kemampuan Hafalan Al-Quran Anak-Anak Melalui Kegiatan Taman Pendidikan Al-Quran Di Desa Nijang Kabupaten Sumbawa Besar," Jurnal Pengabdian Magister Pendidikan IPA 4, no. 1 (2021): 2-5, https://doi.org/10.29303/jpmpi.v4i1.591.

${ }^{37}$ Irma Lestari, "PENERAPAN METODE MENGHAFAL (FUN TEORY) DAN PROBLEMATIKANYA DALAM PEMBELAJARAN AL-QUR'AN HADITS DI MTs NEGERI 1 LANGSA," Al-Ikbtibar: Jurnal Ilmu Pendidikan 6, no. 2 (2020): 663-74, https://doi.org/10.32505/ikhtibar.v6i2.607. 
begitu, menghafal merupakan salah satu aktivitas efektif yang membantu merekam memori otak dalam jangka panjang. Dan membantu menstimulus jaringan otak untuk terus berfikir dan menjelajahi hal-hal lain yang ingin dikembangkan dari kegiatan menghafal tersebut.

\section{Tayangan Film Islami}

Kegiatan menonton bersama tayangan film-film Islami dilakukan setiap satu minggu sekali dengan tayangan animasi Islami. Hal ini dilakukan dalam rangka mengembangkan karakter religius pada anak melalui pendekatan pengalaman, pembiasaan, dan keteladanan dan membiasakan anak untuk memberikan kesimpulan dari apa yang telah ditontonya. Tujuannya selain membuat anak mengerti hikmah dari apa yang sudah di tonton juga melatih mental percaya diri terhadap anak.

Ali Musyafak berpendapat bahwa Film Islami merupakan suatu film dakwah yang mempunyai peran sebagai penyampaian nilai dan moral, di mana pesan-pesan yang terkandung dapat tersampaikan dan menjadikan seseorang lebih baik. ${ }^{38}$ Contohnya seperti film kartun Nusa dan Rara. Tayangan kartun tersebut merupakan salah satu bentuk penguatan moral yang dilakukan melalui pemanfaatan teknologi dan industrialisasi perfilman. Bahkan, dengan adanya penayangan kartun tersebut, memudahkan anak-anak dalam memahami hal-hal dalam ajaran Islam menjadi lebih mudah, efektif, efisien dan tentunya menyenangkan.

Film adalah sebuah media massa yang mampu bergerak dan memiliki bentuk dominan dari komunikasi massa visual di belahan dunia ini. Bagi kalangan pecinta film beranggapan bahwa film merupakan karya seni yang diproduksi secara kreatif dan memenuhi imajinasi orang-orang yang bertujuan untuk memperoleh estetika (keindahan) yang sempurna. ${ }^{39}$ Maka dari itu, upaya program film Islami yang dilakukan oleh Kepala Desa Langkap, dusun Bringin, Besuki, Situbondo dapat menjadi strategi yang cukup tepat. Sebab, Sebagian besar generasi muda saat ini telah kecanduan teknologi sehingga terpengaruh dampak negatif yang ada.

Film Islami memiliki peran yang sangat penting terhadap pengembangan karakter religius. Selain berfungsi menghibur, film Islami juga mampu mengembangkan karakter religius anak-anak tentunya dengan cerdas dalam

${ }^{38}$ Omar et al., "Analisis Nilai-Nilai Agama Dan Moral Anak Usia Dini Pada Film” 5, no. 02 (2021): 221-32.

${ }^{39}$ Sayekti and Octavian Muning, "Film Animasi Nussa Dan Rara Episode Baik Itu Mudah' Sebagai Sarana Penanaman Karakter Pada Anak Usia Dini," Jurnal Pendidikan Anak 8, no. 2 (2019): 164-71, https://doi.org/10.21831/jpa.v8i2.29093. 
memilih sebuah tayangan Islami. ${ }^{40}$ Peran penting dari Film Islami ini dalam membentuk dan menanamkan karakter religius menjadi upaya yang terus dilakukan dan terus diinovasikan dalam bentuk penayangannya. Itu karena dampak yang diberikan cukup signifikan dalam membentuk karakter pada diri anak.

\section{KESIMPULAN}

Melalui kegiatan-kegiatan yang yang dilakukan pemerintah desa yang bekerja sama dengan orang tua dan masyarakat untuk menanggulangi anak yang kecanduan bermain game online yakni dengan menanamkan nilai karakter religius secara perlahan pada anak melalui kegiatan yang ada yaitu : 1) Gerakan Magrib mengaji 2) Pembacaan Shalawat nariyah 3) Hafalan rutinan 4) dan Tayangan film Islami. Penanggulangan melalui pendidikan karakter religius pada anak yang dilakukan sejauh ini terus mengalami perkembangan dalam hal antusiasme anak, salah satunya anak menjadi lebih semangat melakukan hal-hal bermanfaat karena dilakukan secara bersama-sama.

Implikasi dalam penanggulangan kecanduan game online melalui pendidikan karakter religius menjadikan salah satu dampak positif bagi anak yaitu anak tidak terus-menerus terpaku pada permainan game online, dan menjadikan anak cenderung melakukan hal-hal yang lebih bermanfaat dan memiliki kepribadian yang lebih baik dari sebelumnya. Walau demikian penanggulangan melalui pendidikan karakter religius yang diberikan tidak selalu berjalan lancar dan baik sebab tidak semua anak tertarik untuk melakukan kegiatan-kegiatan agama. Dengan begitu, peneliti berharap kajian ini dapat bermanfaat bagi berbagai pihak dan akademisi sebagai sumber rujukan relevan untuk melakukan penelitian serupa serta mengkaji ulang agar sesuai dengan kondisi yang dihadapi. Peneliti juga mengucapkan terimakasih kepada berbagai pihak yang telah membantu dan mendukung penelitian ini.

\section{BIBLIOGRAFI}

Amran, Ali, Marheni, Eddy, Sin, Hauw, Tjung, Yenes, and Ronni. "Kecanduan Game Online Mobile Legends Dan Emosi Siswa Sman 3 Batusangkar." Jurnal Patriot 2, no. 4 (2020): 1118-30.

Arkani, and Hari. "Pembentukan Kepribadian Oleh Guru Melalui Pendidikan Karakter Di SMA Puspita Kabupaten Banyuasin.” Prosiding Seminar Nasional 20 Program Pascasarjana Universitas PGRI Palembang, no. November (2017):

${ }^{40}$ Marpuah et al., "Peran Tayangan Film Islami Dalam Pengembangan Karakter Religius" 5, no. 01 (2021): 123-32. 
84-91.

Arta Jaya, Kadek. "Membangun Mutu Pendidikan Karakter Siswa Melalui Implementasi Ajaran Tri Hita Karana." Jurnal Penjaminan Mutu 5, no. 1 (2019): 57. https://doi.org/10.25078/jpm.v5i1.759.

Chandra, Pasmah, Marhayati, Nelly, and Wahyu. "Pendidikan Karakter Religius Dan Toleransi Pada Santri Pondok Pesantren Al Hasanah Bengkulu." AlTadrkiyyah: Jurnal Pendidikan Islam 11, no. 02 (2020): 111-32.

Chusna, Asmaul, and Puji. "Pengaruh Media Gadget Pada Perkembangan Karakter Anak." Dinamika Penelitian: Media Komunikasi Sosial Keagamaan 17, no. 2 (2017): 315-30.

Fahruroji \& Yunus Chairul Azhar. "Perspektif Shalawat Di Dalam Al-Qur'an Dan Al-Hadits Serta Implikasinya Di Dalam Penafsiran Dan Penetapan Hukum." Jurnal Pendidikan BASIS Bahasa Arab Dan Studi Islam 1, no. 1 (2017): 31-40.

Ismi, Nurul, and Akmal Akmal. "Dampak Game Online Terhadap Perilaku Siswa Di Lingkungan SMA Negeri 1 Bayang." Journal of Civic Education 3, no. 1 (2020): 1-10. https://doi.org/10.24036/jce.v3i1.304.

Jumanah, Jumanah, Badrussalam, and Ujang. "Revolusi Mental Melalui Penerapan Kebijakan Gerakan Magrib Mengaji Di Kabupaten Lebak." Transparansi: Jurnal Ilmiah Ilmu Administrasi 3, no. 2 (2020): 160-66. https://doi.org/10.31334/transparansi.v3i2.1098.

Kartika, Rika, Nurman, and Nurman. "Pelaksanaan Gerakan Masyarakat Magrib Mengaji Di Nagari Lubuk Basung Kabupaten Agam." Journal of Civic Education 1, no. 2 (2018): 141-48. https://doi.org/10.24036/jce.v1i2.185.

Kurniawan, Drajat Edy. "Pengaruh Intensitas Bermain Game Online Terhadap Perilaku Prokrastinasi Akademik Pada Mahasiswa Bimbingan Dan Konseling Universitas PGRI Yogyakarta.” Jurnal Koseling Gusjigang 3, no. 1 (2017): 97-103.

Lestari, Irma. "PENERAPAN METODE MENGHAFAL (FUN TEORY) DAN PROBLEMATIKANYA DALAM PEMBELAJARAN ALQUR'AN HADITS DI MTs NEGERI 1 LANGSA.” Al-Ikhtibar: Jurnal Imu Pendidikan 6, no. 2 (2020): 663-74. https://doi.org/10.32505/ikhtibar.v6i2.607.

Marpuah, Sri, Priatna, Oking Setia, Ibn, Universitas, Khaldun Bogor, Karakter Agama, and Pengembangan Sikap. "Peran Tayangan Film Islami Dalam Pengembangan Karakter Religius” 5, no. 01 (2021): 123-32. 
Mufidah, Rizqotul Luqi, Farida, and Norma Azmi. "Tradisi Sholawat Mansub Habib Sholeh Bin Muhsin Al-Hamid Di Tempeh Tengah, Lumajang." Jurnal Living Hadis 5, no. 1 (2020): 59. https://doi.org/10.14421/livinghadis.2020.2205.

Munif, Muhammad, Rozi, Fathor, Yusrohlana, Siti, and Universitas Nurul Jadid. "STRATEGI GURU DALAM MEMBENTUK KARAKTER SISWA MELALUI NILAI-NILAI KEJUJURAN.” Fondatia: Jurnal Pendidikan Dasar 5, no. 2 (2021): 163-79.

Napiah, Napiah, Idrus, and Agil Al. "Meningkatkan Kemampuan Hafalan AlQuran Anak-Anak Melalui Kegiatan Taman Pendidikan Al-Quran Di Desa Nijang Kabupaten Sumbawa Besar." Jurnal Pengabdian Magister Pendidikan IPA 4, no. 1 (2021): 2-5. https://doi.org/10.29303/jpmpi.v4i1.591.

Niam, Zainun Wafiqatun. "Membina Karakter Anak Melalui Program Full Day School Berbasis Nilai-Nilai Kepesantrenan (Studi Kasus Di Madrasah Ibtidaiyah Nurul Ummah Kotagede Yogyakarta)." BELAJEA: Jurnal Pendidikan Islam 4, no. 1 (2019): 19. https://doi.org/10.29240/belajea.v4i1.696.

Novrialdy, and Eryzal. "Kecanduan Game Online Pada Remaja : Dampak Dan Pencegahannya Online Game Addiction in Adolescents: Impacts and Its Preventions" 27, no. 2 (2019): 148-58. https://doi.org/10.22146/buletinpsikologi.47402.

Nurbaiti. "Kecanduan Bermain Game Online Dan Hubungannya Dengan Pendidikan Karakter Islami Siswa (Studi Di SD Azhari Cilandak Jakarta)." Jurnal Kajian Ilmu Dan Budaya Islam 3, no. 1 (2020): 55-67.

Oktari, Dian Popi, and Aceng Kosasih. "Pendidikan Karakter Religius Dan Mandiri Di Pesantren." Jurnal Pendidikan Ilmu Sosial 28, no. 1 (2019): 42. https://doi.org/10.17509/jpis.v2811.14985.

Omar, Animasi, Hana, and Dan. "Analisis Nilai-Nilai Agama Dan Moral Anak Usia Dini Pada Film” 5, no. 02 (2021): 221-32.

Pebriana, Putri Hana. “Analisis Penggunaan Gadget Terhadap Kemampuan Interaksi Sosial Pada Anak Usia Dini." Jurnal Obsesi : Jurnal Pendidikan Anak Usia Dini 1, no. 1 (2017): 1. https://doi.org/10.31004/obsesi.v1i1.26.

Purandina, Yoga, Putu, I, Winaya, Astra, and I Made. "Pendidikan Karakter Di Lingkungan Keluarga Selama Pembelajaran Jarak Jauh Pada Masa Pandemi COVID-19." Cetta: Jurnal Ilmu Pendidikan 3, no. 2 (2020): 270-90. https://doi.org/10.37329/cetta.v3i2.454. 
Rahmi, Rina, Aswatun Hasanah, and Septika Laily Anti. "Konsep Pendidikan Karakter Pada Sekolah Inklusi Tingkat Usia Dasar." AR-RLAYAH: Jurnal Pendidikan Dasar 4, no. 2 (2020): 155. https://doi.org/10.29240/jpd.v4i2.1648.

Retnasari, Lisa, Suyitno Suyitno, and Yayuk Hidayah. "Penguatan Peran Taman Pendidikan Al-Quran (TPQ) Sebagai Pendidikan Karakter Religius." Jurnal SOLMA 8, no. 1 (2019): 32. https://doi.org/10.29405/solma.v8i1.2968.

Rozi, Fathor, and Innani Kholidatul Jannah. "Revitalisasi Pemberdayaan Budaya Karakter Nuansa Religiustik Dalam Membentuk Perilaku Pekerti Santri." Murobbi: Jurnal Ilmu Pendidikan 5, no. 1 (2021): 17-34.

Saihu, Saihu. "Pendidikan Karakter Berbasis Kearifan Lokal (Studi Di Jembrana Bali)." Edukasi Islami: Jurnal Pendidikan Islam 8, no. 01 (2019): 69. https://doi.org/10.30868/ei.v8i01.364.

Salis Hijriyani, Yuli, and Ria Astuti. "Penggunaan Gadget Pada Anak Usia Dini Dalam Menghadapi Era Revolusi Industri 4.0.” ThufuLA: Jurnal Inovasi Pendidikan Guru Raudhatul Athfal 8, no. 1 (2020): 015. https://doi.org/10.21043/thufula.v8i1.6636.

Saputra, Ganda Ade. "Masyarakat Magrib Mengaji” 15, no. 2 (2019): 164-70.

Sayekti, and Octavian Muning. "Film Animasi 'Nussa Dan Rara Episode Baik Itu Mudah' Sebagai Sarana Penanaman Karakter Pada Anak Usia Dini." Jurnal Pendidikan Anak 8, no. 2 (2019): 164-71. https://doi.org/10.21831/jpa.v8i2.29093.

Setyaningrum, Yanurus, Husamah, and H. "Optimalisasi Penerapan Pendidikan Karakter Di Sekolah Menengah Berbasis Keterampilan Proses: Sebuah Perspektif Guru IPA-Biologi." Jurnal Penelitian Dan Pemikiran Pendidikan 1, no. 1 (2020): 69-81.

Setyowati, and Dewi Liesnoor. "Pendidikan Kebencanaan." Urgensi Pendidikan Mitigasi Bencana, 2019, 1-14.

Siswanto, Siswanto, Ifnaldi Nurmal, and Syihab Budin. "Penanaman Karakter Religius Melalui Metode Pembiasaan." AR-RLAYAH: Jurnal Pendidikan Dasar 5, no. 1 (2021): 1. https://doi.org/10.29240/jpd.v5i1.2627.

Soetrisno, Djoko, Yoku, and Onesimus. "PERILAKU AGRESIF PADA SISWA SMP YANG BERMAIN GAME ONLINE." Tjyybjb.Ac.Cn 3, no. 2 (2019): 58-66.

Suharyanto, and Cosmas Eko. "Peran Teknologi Informasi Dan Komunikasi (Tik) Sebagai Enabler Knowledge Management Dalam Membawa Inovasi 
Pada Industri Kreatif Di Batam,” no. 1322202122 (2019). https://doi.org/10.31227/osf.io/ag2nk.

Syaroh, Lyna Dwi Muya, and Zeni Murtafiati Mizani. "Membentuk Karakter Religius Dengan Pembiasaan Perilaku Religi Di Sekolah: Studi Di SMA Negeri 3 Ponorogo." Indonesian Journal of Islamic Education Studies (IJIES) 3, no. 1 (2020): 63-82. https://doi.org/10.33367/ijies.v3i1.1224.

Tohet, Moch, and Ida Rositha. "Penguatan Kurikulum 2013 Dalam Menumbuhkan Karakter Peserta Didik Di Sekolah.” Jurnal At-Tarbiyat 1, no. 2 (2019). https://doi.org/10.30649/ fisheries.v1i2.23.

Tomohon, and D I Kota. "Peran Dinas Sosial Dalam Penanggulangan Kenakalan Anak Remaja Di Kota Tomohon." Jurnal Politico 10, no. 4 (2021).

Ulfa, and Mimi. "Effect of Addiction Online Game Center." Jom. Fisip 4, no. 1 (2017): 1-13.

Widodo, Hendro. "Penguatan Pendidikan Karakter Di SD Muhammadiyah Macanan Sleman Yogyakarta." Jurnal Lentera Pendidikan 22, no. 1 (2019): 40-51.

Wijoyo, and Hadion. "Peranan Lohicca Sutta Dalam Peningkatan Pendidikan Karakter Dosen Di STMIK Dharmapala Riau." Jurnal Guru Kita 3, no. 4 (2019): 315-22.

Zakariya, Din Muhammad. "METODE MUDAH MENGHAFAL ALQUR'AN MENURUT DR. AHMAD SALIM." Jumal Pendidikan Islam 9, no. 2 (2019): 33-47.

Zubir, Zahriyanti, and Yuhafliza. "Pengaruh Media Sosial Terhadap Anak Dan Remaja." Pendidikan Almuslim VII, no. 1 (2019): 10-15. 